\title{
EVALUASI PEMAPARAN PROGRAM KERJA TIAP POSKO
}

\author{
TITIK ANRIANI \\ 9173770410126 \\ doraemon211205@gmail.com
}

1. Bentuk Kegiatan

Evaluasi Pemaparan Program Kerja Tiap Posko

\section{Lokasi}

Lembah Hijau Rumbia

3. Hari/Tanggal dan Waktu

Rabu,/14-10-2020 jam 12:20 s/d 16:03

4. Peserta yang Dilibatkan

- Mahasiswa KKLP

- Ketua Panitia

- Dosen Pembimbing

- Kordes Dan jajarannya

- Korcam dan jajarannya

\section{Alasan Diadakannya}

Untuk dapat memaparkan program kerja kepada dosen pembimbing dan ketua panitia

9. Referensi Wajib

- HERIANTO, H., \& Amir, A. S. (2020, September 10). Pedoman Pelaksanaan Kuliah Kerja Lapangan Plus (KKLP) Mahasiswa STIE dan STKIP YAPTI Jeneponto. https://doi.org/10.31219/osf.io/7dvpk

\section{Tujuan dan Manfaat}

Tujuan dan manfaat untuk dapat diketahui program-program kerja yang ada di tiap posko

7. Produk Kegiatan (Jika Ada)

8. Deskripsi Kegiatan

Pemaparan Program kerja ini dilaksanakan pada siang hari setelah selesai sholat dzuhur.dan di hadiri oleh ketua panitia,dosen pembimbing,dan ketua STIE. 